\title{
Public Satisfaction with Information Services in Public Services
}

\author{
Nila Mulia Sari ${ }^{1}$, Muh. Iqbal Sultan ${ }^{2}$, Tuti Bahfiarti ${ }^{3}$ \\ Program Studi Ilmu Komunikasi Fakultas Ilmu Sosial dan Ilmu Politik, Universitas \\ Hanasuddin, Jalan Perintis Kemerdekaan KM. 10 Makassar 90245 1,2,3 \\ \{nilamulia60@gmail.com¹,miqsul1012@gmail.com², tutibahfiarti@yahoo.com³
}

\begin{abstract}
Information services provided by the Public Service Mall by the Palopo City One-Stop Investment Service (DPMPTSP) is a breakthrough that sought to increase public satisfaction in the city of Palopo. This study investigates how public satisfaction with information services was carried out by Public Service Mall (DPMPTSP). This research uses quantitative research methods with a random sampling technique $(n=40)$. The results of this study indicate that the information services provided by the Public Service Mall DPMPTS Palopo City make the public feel satisfied through indicators; (1), Building an information system (2), establishing a list of information (3), providing facilities and infrastructure (4), Information complaint services. This research's contribution is expected to be an innovation in improving public services in all government sectors.
\end{abstract}

Keywords: Information Services; Public Satisfaction; Service Mall; DMPTSP

\section{Introduction}

Public Service Malls' presence is a breakthrough from the government in Indonesia to provide services that can satisfy people in various regions to be facilitated in managing various things because of the transparent process. The time is following Standard Operating Procedures. As service users fix various public service quality deficiencies, the government has formed a Public Service Mall. In connection with that matter. The Public Service Mall itself has a goal of making the service process easier.

Public Service Mall is a breakthrough from the government in providing goods, services, and administrative services. This is an expansion of regional integrated service functions and services for State-Owned Enterprises, Private-Owned Enterprises to provide services that make the public more comfortable and more accessible with the public service system, which is in one location with service activities and others that are tied to one another. One of the agencies located in the Public Service Mall is the One-Stop Services Investment Agency (DPMPTSP) as the organizer of the Public Service Mall, which acts as the operational controller of the Public Service Mall management. The Head of the Investment Service and One-Stop Integrated Service is obliged to convey, communicate and receive participation in services carried out at Public Service Malls. 
The service mechanism provided falls under the Investment Service and One-Stop Integrated Services' authority, which is implemented by statutory regulations. The provision of services is carried out based on standard operating procedures, providing information services at the Investment Service and One-Stop Integrated Services. The public's satisfaction level will assess the provision of information services to carry out the licensing process. The assessment provided by the public determines the performance measurement of information services at the Investment Service and One-Stop Services. Activities that can be done to determine information services are to measure the level of public satisfaction. Public satisfaction affects the quality of information services provided at the Investment Service and One-Stop Integrated Services as the Public Service Mall organizer. It is an exciting thing to study because it intends to find out more about the level of public satisfaction with information services at Public Service Malls (MPP).

\section{Literature Review}

\subsection{Service Information}

Services Information services are services that are needed by the public in doing something. The purpose is to make it easier for individuals to have the knowledge (information) they want. Both information related to themselves or about life in their environment, and to make the source of knowledge that individuals need in carrying out the service process so that the service is easier to make plan decision-making (Nurihsan, 2011:19).

The position of information service in an organization can be described by Moerdick (1982) as the flow of blood in the human body. This analogy shows how vital information is for the sustainability of an organization. As the "blood" of information in an organization, information is an essential element that can make the organization grow more rapidly and accelerate various activities carried out by the organization in making policies.

The elements that are the conditions for the birth of information in an organization include the human element (reasoning device), hardware, and software. (Nugroho, 2005). So important is this element that it becomes a unit that has a continuous relationship with one another. Every member of the organization must maintain the elements that make up this unity to achieve the mission of conveying information of high quality and can be disseminated to all parts of the organization's members.

\subsection{Service Satisfaction Theory}

Satisfaction can be obtained by the public when public expectations are met with the services it receives. According to Kotler (2009: 49), customer satisfaction is a feeling where someone feels happy or disappointed with the results that have been obtained from the product they receive compared to their expectations. According to Tjiptono (2006: 65), customer satisfaction or dissatisfaction is the customer's responsibility to evaluating the perceived dissatisfaction (disconfirmation) between previous expectations or other performance expectations and the product's actual performance, that is, felt after using it. Providing service quality means consistently compromising with customer expectations. "Bates and Hoffman (1999), as quoted by Sukoco and Nilowardono (2009), state that service quality is a custom assessment of the service provision process, thus evaluating service quality means evaluating to the service production process Satisfaction is the level of feeling where someone states the 
results of the comparison of the performance of the product (service) received and expected (Lupiyoadi and Hamdani, 2008: 192). Customer satisfaction is the basis for a service system that is responsive to customer needs, minimizing costs and time, and maximizing service to the impact of the target population. Service quality is an attitude from comparing the expectation of the quality of consumer services with the company's performance that is felt by consumers (Usmara, 2008: 42).

\subsection{Information Service Indicators}

In the information commission regulation number 1 of 2010 concerning public information service standards, article 4 consists of 4 indicators directly related to government agencies' services. The standard indicators for public information services are:

a. Build and develop information and documentation systems to manage Public Information efficiently and adequately;

b. Establish and periodically update the List of Public Information for all managed Public Information;

c. Provide facilities and infrastructure for Public Information services, including announcement boards and information desks at every Public Agency office, as well as an official website for State Public Bodies

d. Information complaint service responds to the Public Information Applicant's objection who submits the objection.

\section{Research Methodology}

The research is located at Mall Public Services at the Investment Service Agency for the One-Stop City of Palopo. The agency becomes the organizer in acting and controlling Public Service Mall operationally using quantitative descriptive research.

Quantitative descriptive research in this study is the presentation of data through tables, graphs, pie charts, pictograms, calculation of mode, median, mean, calculation of deciles, percentiles, calculation of data distribution through calculating the mean and standard deviation, calculation of percentages. In quantitative descriptive research, it can also be done by looking for the strength of the relationship between variables through correlation analysis, making predictions with regression analysis, and making comparisons by comparing the average sample or population data. The significance does not need to be tested, so technically, it can be seen that in descriptive statistics, there is no there is significance test, there is no level of error because the researcher does not mean to make generalizations, so there are no generalization errors.

For the relative frequency distribution formula, namely:

$\mathrm{F}$ relative $=\frac{\mathrm{F}}{\mathrm{n}} \times 100 \%$

Description:

Frelative: The frequency being sought percentage

f: frequency number

$\mathrm{n}$ : number of data / respondents

Researchers' data measurement scale is the Likert scale, which is a measurement used to measure attitudes, opinions, and perceptions of a person or group of people about social phenomena. Respondents will be allowed to answer each statement by choosing one of the 
answers provided; each answer has a different weighting score, namely: Very Satisfied (5), Satisfied (4), Quite Satisfied (3), Not Satisfied (2), and Very Dissatisfied (1).

The sample used in this study is the public who comes directly to the One-Stop Integrated Service Investment Service with a stratified random sampling technique. Samples that can be taken to represent the population are obtained by determining the number of samples according to Hair et al. in this study depending on the number of indicators multiplied by 4 to 10. The number of indicators in this study is four indicators so that the number of samples that can be drawn is then multiplied by four indicators to 40 samples.

\section{Result and Discussion}

\section{Public Satisfaction with Information Services in Public Service Malls}

Information services provided by the One-Stop Investment Service for the City of Palopo have increased public satisfaction. This information service is provided based on the information service program plan formulated to implement information service activities. The following is a recapitulation of the questionnaire responses that respondents have given related to information service activities that have been carried out:

\section{a) Building Information Systems}

Table 1. Building Information Systems

\begin{tabular}{lccc}
\hline The Answer Choices & Score & Frequency & Percentage \\
\hline Very satisfied & 5 & 10 & $25 \%$ \\
Satisfied & 4 & 23 & $57.5 \%$ \\
Quite satisfied & 3 & 7 & $17.5 \%$ \\
Dissatisfied & 2 & 0 & $0 \%$ \\
Very dissatisfied & 1 & 0 & $0 \%$ \\
& & & $100 \%$ \\
\hline
\end{tabular}

Source: Results of Data Processing Primary 2020

Based on the table above, the results of data processing that researchers have carried out show that to provide information services from 40 respondents, 23 respondents are satisfied with information services, with a percentage of $57.5 \%$. It can be said that Building Information Systems plays a significant role in providing information services to the level of public satisfaction at the Palopo City One-Stop Investment Service, which continues to carry out activities to provide information to the public.

\section{b) Establishment of Direct and Online Information Lists}

Table 2. Employees List Information Directly and Online with

\begin{tabular}{lccc}
\hline Choice Answers & Score & Frequency & Percentage \\
\hline Very satisfied & 5 & 8 & $20 \%$ \\
Satisfied & 4 & 25 & $62.5 \%$ \\
Quite satisfied & 3 & 7 & $17.5 \%$ \\
Dissatisfied & 2 & 0 & $0 \%$ \\
Very dissatisfied & 1 & 0 & $0 \%$ \\
& & & $100 \%$ \\
\hline
\end{tabular}

Source: Results Primary Data Processing 2020 
Based on the table above, it can be seen that from 40 respondents, 25 respondents are satisfied with the service of employees who determine the list of information directly and online with a percentage of $62.5 \%$, meaning that respondents are satisfied with the service of employees who provide a list of information. Employees of the One-Stop Integrated Service Investment Service have provided a list of information about types of licensing. Such as online permits, services, complaints, customer surveys, and pick-up services. If the public who has carried out the permit wants to be delivered directly to the One-Stop Integrated Service Investment Service location, provide information both online and offline. Employees load various information and forms from 22 available permits.

\section{c) Provision of Facilities and Infrastructure}

Table 3. Provision of Facilities and Infrastructure for the Public with

\begin{tabular}{lccc}
\hline Choice Answer & Score & Frequency & Percentage \\
\hline Very satisfied & 5 & 14 & $35 \%$ \\
Satisfied & 4 & 18 & $45 \%$ \\
Quite satisfied & 3 & 8 & $20 \%$ \\
Dissatisfied & 2 & 0 & $0 \%$ \\
Very dissatisfied & 1 & 0 & $0 \%$ \\
& & & $100 \%$ \\
\hline
\end{tabular}

Source: Results of 2020 Primary Data Processing

Based on the table above, it can be seen from 40 respondents that 18 respondents were satisfied with the provision of facilities and infrastructure with a percentage of $45 \%$. It means that respondents were satisfied with the availability of facilities and infrastructure for information services. Employees of the One-Stop Integrated Service Investment Service had provided facilities and infrastructure in the form of information desks, banners, and brochures to help people get information when they come to do permits. The existence of facilities and infrastructure is fundamental because it is always in touch with people with different interests and goals. Therefore, facilities and infrastructure are significant because they can bridge the people who come by providing assistance and convenience to the community to fulfill management at the Palopo City One-Stop Investment Service.

\section{d) In-person and Online Information Complaint Service}

Table 4. Information Complaint Services Directly and also Online

\begin{tabular}{lccc}
\hline Choice of Answer & Score & Frequency & Percentage \\
\hline Very satisfied & 5 & 10 & $25 \%$ \\
Satisfied & 4 & 22 & $55 \%$ \\
Quite satisfied & 3 & 8 & $20 \%$ \\
dissatisfied & 2 & 0 & $0 \%$ \\
Very dissatisfied & 1 & 0 & $0 \%$ \\
& & & $100 \%$ \\
\hline
\end{tabular}

Source: Results Primary Data Processing 2020

Based on the table above, it can be seen that from 40 respondents, 22 respondents are satisfied with direct and online information complaint services, namely 55\%. It means that respondents are satisfied with employees who complete complaint services according to the applicable mechanism. Employees of the One-Stop Integrated Service Investment Service 
have providing complaint information services through the Ministry of Communication and Information have created a reporting system with the name $s 4 n$ reports. So that complaints from the public will be entered on the report $s 4 n$ and from the One-Stop Integrated Service Investment Service will follow up on the report.

The results of questionnaire data processing from four information service indicators, including building an information system, establishing a list of information, providing facilities and infrastructure, and providing direct and online information complaint services, are in the satisfied category. Thus it can be concluded that the public response to information services at the One-Stop Services Investment Service is "satisfied" with the indicators of information services.

Activities Information services that want to be carried out need planning preparations carried out because of the importance of information in the organization to facilitate all activities in an organization. Moerdick (1982) states the organization's position of information as blood flow in the human body. This analogy shows how vital information is for organizational life. As the "blood" of an organization, information is one of the essential elements that can live, develop and streamline organizational activities both at the policymaking and operational levels.

Based on the results of data processing from research, the public is very receptive to any information provided by the One-Stop Integrated Service Investment Service and impacts the effects. The public gets factual information from the One-Stop Integrated Service Investment Service and then follows all directions given. The information obtained comes from services provided directly to the public who come to the One-Stop Integrated Service Investment Service and services performed using the media. Services that are performed using the web can streamline the public's time because they no longer need to come directly to the location to carry out-licensing arrangements. Gathering this information is our natural way to understand our interlocutors later to build a good relationship in a communication (Littlejohn \& Foss, 2009).

Public satisfaction is the main factor that public service providers must consider because public satisfaction will determine public service organizations' success. The definition of public satisfaction is usually equivalent to the customer or consumer satisfaction created through the government's performance, in this case, the One-Stop Integrated Service Investment Service.

Assessing the quality of information services is not a very easy activity, especially the provision of public service delivery systems that are administrative. However, apart from these problems, quality problems usually lie with providers who do not supply and encourage interactive human resources and provide technical guidance on quality improvement.

Following the theoretical view used by researchers that satisfaction theory describes the satisfaction of consumers. In terms of the communication aspect, to achieve a word of satisfaction, what must be active to bridge this is communication. Communication becomes flexible in directing the information service. According to researchers, what the city government of Palopo uses in improving the public service system is strategic but not yet optimal. In this study, it is also illustrated that analyzing services must involve a maximum approach. In other words, they were using persuasive communication where all services are humanist and practical means that people no longer feel ashamed and afraid to carry out any information services in Palopo.

According to researchers, there are no reports and criticisms regarding the information service system in Palopo City. Quality improvement is not calculated from the presence or absence of reports on the service system but seen from the information disclosure and service 
quality with super active and dynamic approaches and carried out by the government, in this case, the employees on duty.

The availability of information is essential and very much needed for users, in this case, the people of Palopo city. The researcher sees that the media's availability to present information to the public is crucial to the public's attitude towards the One-Stop Integrated Service Investment Service as part of the Public Service Mall in Palopo. Public satisfaction in accessing information has also been excellent; the information service's availability at the One-Stop Investment Service, Palopo City, does not reach this stage only. Of course, this can be said to meet the quality standards of service provision because people are no longer tense, even worried if they want to ask for information.

This is in line with the uncertainty theory's essence; the public and the public sometimes feel worried if they want to consult or ask service providers. In other words, implementing maximum public service standards is expected to provide public services, especially in information services, to produce public satisfaction as the party receiving services. In implementing information service activities, providers are required and expected to apply the principles of effectiveness, efficiency, innovation, and quality commitment. According to researchers, the orientation of public services is consumer and community satisfaction. People get services according to what is expected or even exceed the expectations of the public and society.

The satisfaction of the people of Palopo city with the existing information system is the same as the success of an organization in explaining the organizational information theory and the reduction of uncertainty described by the uncertainty theory. Therefore, as a suggestion for providing information, it must be maintained and up to date, meaning that changes to the information carried out from time to time must be carried out through media that are more quickly accessible to the public and the public.

\section{Conclusion}

This research shows that the One-Stop Integrated Service Investment Service increases public satisfaction with information services. Most of the public is satisfied with the information services provided by the One-Stop Integrated Service Investment Service. The public responds well to all information services carried out by the Service One-Stop Integrated Service Investment. The information service provided by the One-Stop Integrated Service Investment Service has a positive impact on the public, such as cost efficiency and time received by the public. Besides, the public can also receive information wherever they are.

\section{References}

[1] Nurihsan, Juntika. Bimbingan dan Konseling dalam Berbagai Latar Pendidikan. Bandung: PT. Refika Aditama. (2011)

[2] Adi, Nugroho. Analisis dan Perancangan Sistem Informasi Dengan Metodologi Berorientasi Objek. Bandung: Informatika. (2005)

[3] Kotler, Philip. Manajemen Pemasaran (Marketing Management) . Edisi 13. U.S.A: Pearson Prentice Hall. (2009)

[4] Fandy. Strategi Pemasaran. Yogyakarta: Andi Offset. (2006) 
[5] Lupiyoadi, Rambat, dan Hamdani.. Manajemen Pemasaran Jasa. Edisi II. Jakarta: Salemba Empat. (2009)

[6] Usmara, A,. Strategi Baru Manajemen Pemasaran. Jakarta: Amara Books. (2008)

[7] Sukoco, Agus \& Nilowardono, S. Analisa Harapan dan Persepsi Pelanggan atas Servis Quality di PT.PLN (Persero) APJ Surabaya Utara. Jurnal Ekonomi Vol 09 No 2. (2011)

[8] Sugiyono. Metode Penelitian Pendidikan Pendekatan Kuantitatif, Kualitatif, dan R\&D. Bandung: Alfabeta (2014)

[9] Littlejohn, Stephen W \& Karen A. Foss.. Teori Komunikasi, edisi 9. Jakarta: Salemba Humanika. (2009) 